\title{
5 Slowly turning into a 'Country of Immigration'? On the interaction between migration and integration policies in Germany
}

\author{
Nora Ratzmann and Thomas K. Bauer
}

\section{Introduction}

Until the early 2000s, German politicians often refused to accept the country's position as a de facto country of immigration, despite the high share of migrants in the population. Even if ignoring the significant inflow of ethnic Germans directly after World War II, Germany could factually be considered a country of immigration, since at least 1957. Since 1985, net immigration to Germany was positive almost every year, reaching a peak of 1.14 million net immigrants in 2015 (SVR 2019). In 2017, almost 24 per cent of the German population had a 'migration background' - i.e. had immigrated themselves or were the descendants of immigrants (Statistisches Bundesamt 2019).

However, since immigrants were expected to stay only temporarily, a structured integration policy was lacking until recently. The immigration of workers tended only to be possible for certain specialists for a limited amount of time and for EU workers as part of the freedom of movement within the European Union. However, regarding 'ethnic Germans' and, at least compared to many other countries, asylum-seekers and refugees, Germany's immigration policy has been relatively liberal since the aftermath of World War II (see Bauer et al. 2005).

Immigration and integration policies began being adjusted to the new empirical realities from 2000, when the government passed new regulations concerning immigration to Germany, such as the so-called Green Card for non-EU information technology (IT) specialists. Activities culminated in the aligning of the German asylum law with the newly enacted integration law in 2016, following the inflow of more than one million refugees between 2015 and 2016 (SVR 2018, 2019). Most recently, in 2019, the German government submitted several legal proposals to parliament, including regulations concerning the immigration of workers from non-EU countries. If passed, these regulations would mark a historical turn in Germany's migration and integration policy in several respects. Immigration policy towards skilled workers would be liberalised and be refocused on permanent rather than temporary immigration, helping to counter demographic change and the increasing shortage of skilled labour. In light of the recent inflow of refugees, the government also recognised the importance of a more active and structured integration policy. The new migration policy covering labour migrants 
has deliberately been denominated 'immigration' law (Einwanderung) rather than 'inward migration' law (Zuwanderung), which signals that, for the first time, Germany formally calls itself an 'immigration country'.

Against this political backdrop, our chapter discusses the dynamics and interlinkages between immigration and integration policy in Germany after World War II. Following the German Expert Council on Integration and Migration (SVR), we refer to integration as the socio-economic incorporation and socio-cultural adaption to legal - political and cultural - religious norms, which enable newcomers to participate as accepted citizens of the host society (SVR 2018; see also GarcésMascareñas and Penninx 2016). The chapter starts with a review of the data on public attitudes on immigration in Germany. It then situates current policies and politics in their historic context and finishes with a reflection on the degree to which Germany addresses the challenges of migration-related diversity.

\section{Public sentiments towards immigration and integration}

Integration and migration policies may affect the attitudes of German-born nationals towards immigrants, as they can impact on who gains and who loses from immigration. Economic theory predicts that those German citizens whose skills may be substituted by those of immigrants will suffer, while those who have complementary skillsets to those of immigrants will benefit from immigration (Bauer et al. 2000). Hence, sentiments towards immigrants, which may affect their integration, are likely to depend on whether German-born nationals fear the labour market competition of foreigners or whether they expect to benefit from immigration.

Generally, since the substantial inflow of refugees in 2015, the topic of immigration to Germany and the integration of migrants has continuously gained importance in public discussion. According to a 2015 survey, 88 per cent of respondents ranked the issues on immigration as being among the key challenges to Germany society (SVR 2019). The German Socio-Economic Panel (SOEP), one of the largest household panel surveys in Germany, revealed that an increasing part of the German resident population considers immigration to be a concern. While, in 2014, about 26 per cent of respondents in Germany worried about immigration, the percentage rose to 32 per cent in 2015 and to 46 per cent in 2016 - the highest share observed since 1999. In contrast, the percentage of those who did not consider immigration to be an issue halved from 33 per cent in 2014 to 15 per cent in 2016 (Sola 2018). We can note, however, that similar numbers were observed in earlier years. In 1999 and 2005, 36 and 39 per cent, respectively, worried about migration issues while, in both years, about 19 per cent stated 'no worries'.

Other studies, such as a survey carried out by the Bertelsmann Foundation, offer some insights into why immigration might be perceived in such ways (Bertelsmann Stiftung 2015, 2017). In 2012 and 2015, the majority of respondents claimed that immigration is beneficial for Germany because it helps to attenuate demographic change and to dampen the shortage of skilled workers. Immigration was also considered to make life in Germany more interesting and important for foreign investments. Nevertheless, the share of respondents perceiving immigration as beneficial decreased for most items in 2017 (see Figure 5.1). 


\section{Positive impact}

$100 \%$

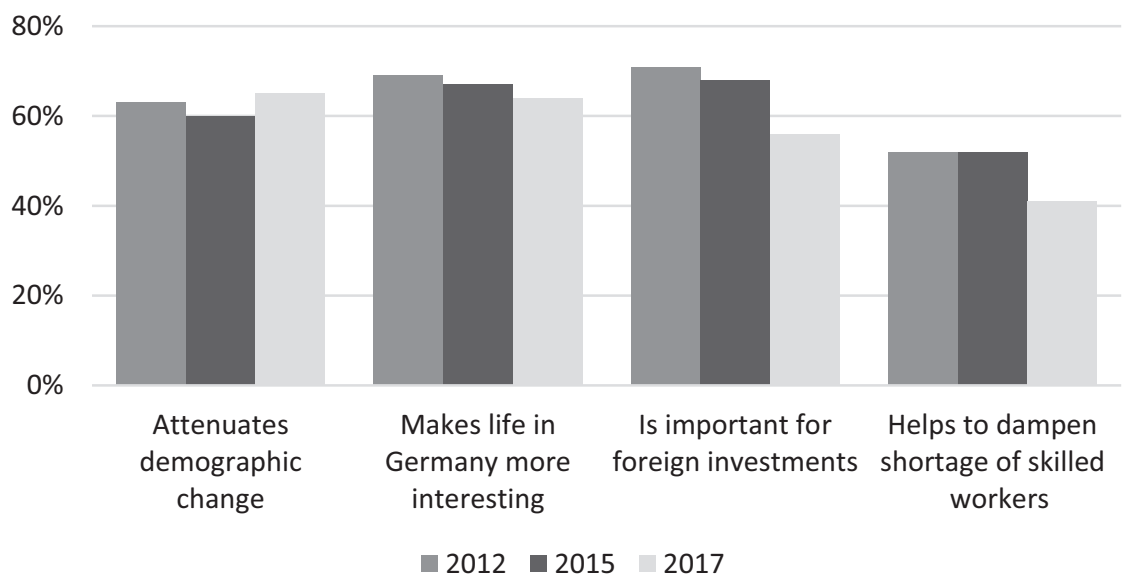

Negative impact

$100 \%$

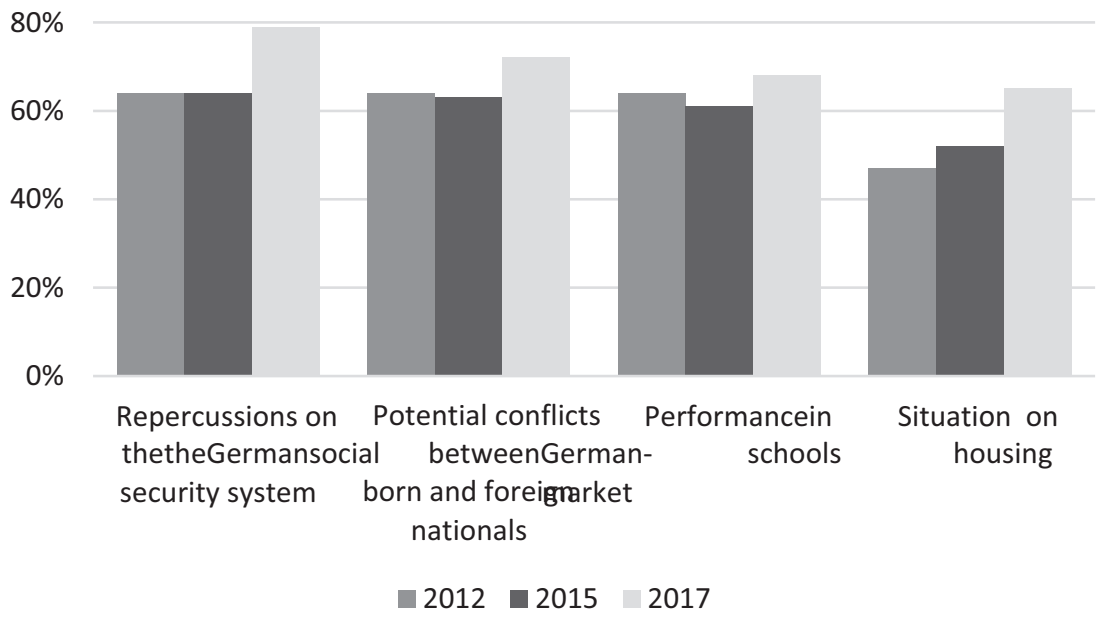

Figure 5.1 Perceptions of the impact of immigration

Source: Based on Bertelsmann Stiftung (2017: 15-17) 
Respondents expressed concerns about the repercussions which immigration might have on the German social security system, on the social fabric regarding conflicts between German-born and foreign nationals, on the performance in schools or on the situation on the housing market. Furthermore, the percentage of respondents sharing these concerns increased in 2017 compared to 2012 and 2015. Yet these numbers consider only the potential benefits and costs of immigration in total and do not differentiate between the different types of immigrant. The inflow of refugees throughout 2015 and 2016 is likely to have affected perceptions on the comparatively higher costs of immigration.

Surveys that ask about people's sentiments towards the immigrants from different countries of origin or of different skill levels support this interpretation. According to recent public attitude data from Eurobarometer (November 2018), the resident population judged the immigration of EU nationals to Germany as more positive than that of third-country nationals. About 71 per cent of the German population considered immigration from other EU member-states to be a positive phenomenon but only 39 per cent felt the same about the arrival of nonEU immigrants. ${ }^{1}$ However, attitudes towards the immigration of both EU and non-EU immigrants overall have become more positive in recent years. Between 2014 and 2018, the percentage of respondents seeing EU immigration as positive rose by 20 per cent and of non-EU migrants by 10 per cent.

A similar picture emerges when asking about attitudes towards the immigration of different types of immigrant. Data from $A L L B U S$, another representative survey of the German resident population, suggested that, in 2006, about 30 per cent ( 8 per cent) of the respondents voted for the unrestricted immigration of workers from the EU (non-EU) respectively, while about 60 per cent ( 65 per cent) opted to restrict this type of immigration and only 11 per cent ( 26 per cent) wanted to prohibit it altogether (SVR 2019: 140). In 2016, almost 48 per cent advocated the unrestricted immigration of EU workers and 19 per cent that of non-EU workers, while only 3 and 12 per cent, respectively, wanted to prohibit labour immigration from these regions (SVR 2019: 140). Asking about attitudes towards the immigration of workers with different skills provides a similar picture. According to a survey by the Expert Council of German Foundations for Migration and Integration, 63 per cent of German nationals think that the number of skilled immigrants should be increased (SVR 2014).

The results are more ambiguous concerning attitudes towards the intake of refugees. According to the ALLBUS survey, the share of Germans voting for the unrestricted immigration of refugees increased from almost 13 per cent in 2006 to 23 per cent in 2016, while the share of respondents asking to stop refugee immigration altogether decreased from 14 to 7 per cent (SVR 2019: 140). In contrast, findings of the Bertelsmann Foundation indicate that attitudes towards refugees became more disapproving over time, especially amongst the older generation. While about 40 per cent of respondents thought Germany should not accept more refugees in 2015, the share rose to 54 per cent in 2017 (Bertelsmann Stiftung 2017). However, a survey by the Expert Council of German Foundations for Migration and Integration in 2015 and 2018 found no clear trend indicating 
whether or not refugees were perceived as a threat to the German economy and the cohesion of its society (SVR 2019).

Surveys conducted by the Bertelsmann Foundation (2017) and by Zick and Preuß (2019) provide some insights into the factors that German nationals consider to be important for immigrants' integration into the host society. Both surveys highlighted the strong expectations which Germany's resident population has of newcomers. In 2015, three out of four respondents expected immigrants to adapt to and assimilate into 'German culture'. Interestingly, though, 80 per cent simultaneously claimed that they would like immigrants to share more of their cultural background with the majority population (Bertelsmann Stiftung 2015). Younger and highly educated respondents had fewer expectations of immigrants' duties to proactively integrate (Bertelsmann Stiftung 2017).

How newcomers could demonstrate their willingness to integrate is mostly related to their acquiring knowledge of German cultural norms, learning the language, being aware of the civic obligations to respect the rules of the political system and the economic conditionality to be engaged in gainful employment, while more formal markers of acquiring German citizenship are of less importance (see Table 5.1). Data collected by the Expert Council of German Foundations for Migration and Integration provide a similar picture. When being asked about the factors that are important when a person aspires to belong to German society, 89 per cent of German-born nationals stated being in work and 65 per cent having German citizenship, 27 per cent following a Christian religion, 25 per cent being born in Germany and 20 per cent having German ancestors (SVR 2019).

In sum, four main messages on attitudes towards immigration and integration in Germany emerge from the review of public attitude data. First, the topic of immigration has gained salience in the public debate, with concerns over immigration issues being on the rise. Second, a high proportion of Germans appears to favour the immigration of EU workers, while the acceptance of immigration from third countries is much lower, although increasing. Thirdly, the inflow of almost one million refugees since 2016 did not change public opinion drastically but

Table 5.1 Indicators of immigrants' obligations in the German society (selection)

\begin{tabular}{|c|c|c|c|c|}
\hline \multirow[t]{2}{*}{ Expected Behaviour (\%) } & \multicolumn{2}{|c|}{$\begin{array}{l}\text { Bertelsmann } \\
\text { (2017) }\end{array}$} & \multicolumn{2}{|c|}{$\begin{array}{l}\text { Zick and Preuss } \\
\text { (2019) }\end{array}$} \\
\hline & 2012 & 2017 & 2014 & 2018 \\
\hline Learn the German language & 96 & 99 & 86 & 92 \\
\hline Respect the German constitution & 91 & 98 & 83 & 87 \\
\hline Work & 86 & 86 & 79 & 78 \\
\hline Adapt to 'German culture' & 73 & 82 & - & - \\
\hline Respect German norms and traditions & - & - & 65 & 72 \\
\hline Acquire German citizenship & 50 & 38 & 48 & 35 \\
\hline Be born in Germany & & & 30 & 23 \\
\hline
\end{tabular}

Source: Based on Bertelsmann Stiftung (2017), Zick and Preuss (2019) 
raised some more critical voices. Finally, the German resident population appears to have strong expectations that newcomers will assimilate into 'German culture' by acquiring knowledge of the German language, norms and values and by participating in the labour market. Traditionally prevailing descent-based markers appear to define belonging to a lower degree.

\section{Immigration and integration policies}

Migration policy may influence the integration of migrants into the host society in several ways (Bauer et al. 2000). To the extent that migration policy is selective, it affects the characteristics of the immigrants. A policy that focuses on the demands of the labour market predominantly attracts migrants whose skills could be easily transferred to the needs of the host country's economy. Such a policy would appear to reduce the necessity of an integration policy, since immigrants are expected to integrate rapidly into the labour market and society. In contrast, the integration of individuals accepted for humanitarian reasons is harder to achieve and involves higher costs, since forced migrants usually did not plan their migration in advance. Compared to labour migrants, their skills could be expected to be less transferable to the needs of the host society which, in turn, increases the necessity of a well-designed integration policy. Integration may also be affected by the extent to which migration policy focuses on permanent or temporary migrants, since the latter may be perceived to have lower incentives to acquire the skills necessary to integrate into the host society, such as language competence. As illustrated in the following paragraphs, these sorts of premise have shaped German political thinking on migration and integration policies.

Historically, Germany's migration and integration policies have been characterised by ethnic understandings of citizenship and belonging, based on descent, shared norms and a common language (Triandafyllidou 2001). The German conception of nationhood relates closely to what Anderson (1983) captured by the term imagined community, which he conceptualised as a symbolic political community, based on shared values, and a common language and descent. Gosewinkel (2016) traced the exclusionary logics that have characterised German citizenship policies since the nineteenth century. This included, among others, the expulsion of Polish workers from Prussia based on their non-German origin and the withdrawal of citizenship rights from the Jewish population living in Germany in the antecedent of World War II.

Strong economic growth and the resulting labour shortages led some European countries to actively recruit immigrants (Bauer et al. 2000). Between 1955 and 1973, the government operated a guestworker scheme, which turned the country into one of the most diverse European countries. About 14 million people came as labour migrants to Western Germany, many of whom stayed, founded families and naturalised (Schierup et al. 2006). These guestworkers were predominantly of Italian, Spanish, Greek and Turkish origin. As Schönwälder (2004) pointed out, policy-makers deliberately sought to recruit white European immigrants. The government practiced a selection based on national origin - for instance, 
excluding Portuguese workers of African or Indian descent. The guestworker policy was terminated in 1973, when Germany experienced an economic downturn in the aftermath of the global oil crisis (Davy 2005). After guestworker recruitment stopped in 1973, migration to West Germany was mainly characterised by the immigration of the family members of those guestworkers who entered the country before 1973. The Eastern half of the country, the German Democratic Republic, also managed a small guestworker programme, recruiting workers from other socialist countries such as Poland, Hungary, Cuba, Vietnam, Angola and Mozambique (Davy 2005).

History may help to gain an understanding of the partially ethnically motivated selection at entry. Compared to its neighbours, the German nation-state emerged relatively late by uniting the fragmented territorial entities of the Holy Roman Empire of the German Nation. The latter was a loose political structure, whose geographic borders were difficult to delineate, bound together as they were by their common traditions and language (Brubaker 1992; MacGregor 2014; Paul 2015). Language defined belonging, mirroring the collective myth of the German nation as an entity 'where people speak German' (Hogwood 2000).

Since the late 1980s, East-West migration and the inflow of asylum-seekers and refugees dominated immigration to Germany. Large parts of the immigrant population were ethnic Germans (Bauer et al. 2005). The repatriation route was closed in the early 1990s, after a heavy inflow of about 1.6 million ethnic Germans following the collapse of the Soviet Union and the former Yugoslavia (Bommes and Geddes 2000). Between 2015 and 2016, the country experienced a renewed influx of almost one million refugees, this time mostly originating from Syria, Iraq and Afghanistan (SVR 2019), of whom almost half were female. Since then, about 35 per cent of them have been granted some form of protection while another 35 per cent had their asylum claim rejected. Syrians and Eritreans were granted protection status in almost all cases (SVR 2019).

German immigration policy has also been characterised by the re-opening of immigration pathways for economic migrants since the 2000s, starting with the IT Green Card, a temporary work permit for IT specialists. The changes coincided with the political realisation that Germany needs immigrant labour to sustain its economic growth and to stabilise its social security system against the background of a dramatic demographic change which manifests itself in a strongly ageing workforce (Kaiser and Paul 2011; Paul 2015). For instance, in 2001, an independent commission chaired by Rita Süssmuth proposed a reform of German immigration policy which, among other changes, envisaged a points system for labour migrants similar to that in Canada or Australia, as well as greater efforts to ensure the integration of migrants (Unabhängige Kommission Zuwanderung 2001). While the points system was not supported by the German parliament, the report of the Commission led to changes in German immigration and integration policy. Moreover, the 2005 Residence Act (Aufenthaltsgesetz) and the most recent EU-wide Blue Card initiative created special legal reception pathways for qualified non-EU workers. State-sponsored visas for up to four years, based on a labour contract with an employer in Germany and minimum earnings of 52,000 euros 
per year, were meant to attract highly skilled labour to fill job shortages (Mourão Permoser 2017; SVR 2018).

The Expert Council of German Foundations on Migration and Integration has qualified the German labour migration scheme for the highly skilled as one of the most liberal schemes worldwide (SVR 2018). Overall, recent policy initiatives could be seen as a continuation of the historic guestworker schemes, premising selective entry depending on labour market needs. However, compared to the guestworker policy, the new policy initiatives aim to foster permanent immigration, since the requirements to obtain a permanent residence permit have also been liberalised. While the Blue Card aims to attract workers from non-EU countries with an academic degree, the German government currently plans to improve the immigration possibilities for skilled workers who do not have one.

However, EU migrant citizens, one of the largest immigrant groups in Germany, are exempt from these rules. Of all the immigrants in Germany in 2017, about two-thirds came from another EU member-state (Bundesamt für Migration und Flüchtlinge 2019). EU Directive 2004/38 (Article 6) stipulates an unconditional right to reside for all EU citizens for the first three months, provided that they hold a valid identity card or passport and that they register their local address with the German authorities. The three-monthly unconditional residence right can be renewed by leaving and re-entering the country. After three months, the rights of EU citizens diverge, depending on their labour market status. Economically inactive EU citizens can only continue to reside in Germany if they are covered by comprehensive health insurance and on condition that they have sufficient financial resources to fund their living. Employed EU citizens can reside indefinitely. After five years of legal and continuous residence, EU migrants can obtain the right to reside permanently, independent of their employment status.

With respect to integration policy, Germany is a latecomer. For decades, the country had declared itself a 'nonimmigration country'. Until the mid-2000s, the idea of supporting migrants' participation in German society had barely surfaced. Guestworkers were assumed to return to their home country instead of settling permanently (Doomernik and Bruquetas-Callejo 2016; Traenhardt 2014). Such an approach fuelled public perceptions of immigrants as foreigners and transient guests (Gosewinkel 2016; Triandafyllidou 2001). The approach delegitimised any state-sponsored pursuit of immigrant integration (Ellermann 2015; Kaiser and Paul 2011). Furthermore, it reduced the incentive for these guestworkers to integrate into German society (Dustmann 1993). Only 'ethnic German' immigrants were granted access to language courses and to special public transfers to foster their integration.

To date, historic ideas of German nationhood as a homogeneous ethno-cultural and linguistic entity continue to shape policies and laws on migrant naturalisation. Germany's immigrant integration regime appears to be dominated by assimilationist elements (Ersanilli 2010), even though recent integration policy points towards some renunciation. In principle, immigrants who settle for at least eight years and who prove their loyalty to the country through language skills and knowledge of 'German culture' are granted German citizenship. While ius sanguinis 
principles tend to dominate naturalisation policy (Brubaker 1992; Ditlmann et al. 2011; Doomernik and Bruquetas-Callejo 2016), the 1990 Aliens Act (Ausländergesetz) and its revised version of the 1999 Citizenship Act, introduced some civic ius soli elements. Nevertheless, naturalisation remains difficult in practice (Amjahid 2017). An exception has been made for 'ethnic repatriates' (Aussiedler) who lived outside the German state boundaries after 1949. Based on their German ties by family origin, 'ethnic repatriates' were recognised as conationals and given immediate and permanent access to German citizenship (Bommes and Geddes 2000; Hogwood 2000).

Nevertheless, over the last decade, German policy has increasingly recognised the empirical reality of Germany as a country of permanent immigration (Ellermann 2015; Kaiser and Paul 2011). State-sponsored integration policies have come into effect quite recently, starting with the 2004 Immigration Law and the 2007 National Integration Plan. The 2005 Immigration Act (Zuwanderungsgesetz) established state-sponsored civic integration and language courses. These courses constitute the central instrument of German integration policy, offering newcomers 600 hours of German language teaching and 100 hours of orientation about Germany's legal system, 'culture' and history (SVR 2019).

Current integration policy seeks to find a balance between the necessity to foster the integration of recent immigrants and efforts to reduce potential pull factors for migrants resulting from fast integration (SVR 2019). For refugees whose countries of origin give them a high probability of being recognised as asylum-seekers and to stay in Germany for a longer period, state-sponsored civic integration and language courses are mandatory and may already begin during the asylum application process. In contrast, refugees with a 'medium probability' of having their status as asylum-seekers recognised are not granted immediate access to these courses. Instead, they have the possibility to attend alternative, less-intensive courses, which provide them with basic language skills as well as some knowledge of German laws and 'culture'. Refugees and asylum-seekers from so-called safe countries are not permitted access to any state-sponsored integration measures. All other immigrants, including EU migrants, may participate in these courses voluntarily and, if they do, are required to contribute financially to cover the costs. Since 2007, family migrants must prove that they have some basic German language skills in order to be allowed to immigrate. Yet this regulation has been amended in the light of a judgement by the European Constitutional Court, which considered the regulation to violate the Treaty of Association of the European Union with Turkey (SVR 2019).

Overall, the political focus has remained on immigration policy, while integration policy has remained either nonexistent or reactive. As one effect, about half of Germany's resident population with a migration background generally tends to have lower qualifications than German-born nationals (Kohn 2015), except for EU migrant groups who often find themselves on the (highly) qualified end of the spectrum (Bruzelius et al. 2015; Foti 2015). The difference in educational background and labour market performance can be explained through a path-dependent, demand-driven migration policy which focused on recruiting 
low-skilled guestworkers to fill unwanted industrial jobs (Bauer et al. 2000). Complemented by family reunification and asylum as the only other legal entry pathways for third-country nationals for many years, selection mechanisms and the absence of a structured integration policy led a structurally deprived immigrant population (Jaehrling and Knuth 2010; Schierup et al. 2006).

Regarding immigrants' social integration, within the comparatively inflexible and hierarchical labour market, low qualifications translate into unemployment and underemployment (Soskice and Hall 2001). Immigrants become shuffled into occupational niches of the labour market - which may not reflect their formal education (Bruzelius et al. 2015; Faist 2013). This relates to their comparatively lower German skills and their foreign, often unrecognised qualifications (Canceedda et al. 2015; Frings 2009). In short, one of the main labour market problems of immigrants lies in the recognition of the skills they obtained in their home countries (Basilio et al. 2017). Partly due to the unique German apprenticeship system and the importance of occupational licences, the recognition of skills is still difficult and costly, even though a law which took effect in 2012 - Gesetz zur Verbesserung der Feststellung und Anerkennung im Ausland erworbener Berufsqualifikationen or Law to Improve the Establishment and Recognition of Professional Qualifications Acquired Abroad - aimed to improve the situation. Survey experiments also suggest that local employers discriminate against job applicants whose name or appearance hints at a foreign descent. Applicants with a migration background are up to 10 per cent less likely to be invited for a job interview than German-born job-seekers (Koopmans et al. 2018). In light of the this, 59 per cent of the respondents in a 2017 representative survey considered discrimination based on their origins as one of the main obstacles to socio-economic integration in Germany; 65 per cent felt that there was a lack of equality of opportunity on the job market (Bertelsmann Stiftung 2017).

Immigrants' socio-economic profile and their experiences of disadvantages in the labour market translate into rates of unemployment and poverty which are more than twice as high for residents with a migration background compared to German-born nationals (Barrett and Maître 2011; Kaiser and Paul 2011; SVR 2018). Immigrants to Germany are not per se more welfare-dependent, since most of the differential in welfare-dependency between German-born nationals and individuals with a migration background can be explained by differences in socio-economic characteristics, such as education or labour market experience (Bauer 2002; Barrett 2012; Barrett and Maître 2011; Wunder and Riphahn 2013). Higher reliance on social assistance-type benefits relates to their household characteristics (Beste et al. 2014; Bruckmeier and Wiemers 2016).

Despite their privileged residence and labour market rights, EU migrants experience similar economic and social problems as third-country nationals residing in Germany. Technically, EU citizens can move to Germany, work there without a work permit or visa and enjoy non-discriminatory treatment compared to thirdcountry nationals (Articles 18 and 21, Treaty on the Functioning of the European Union). However, workers from other EU member-states tend to often only access precarious, atypical jobs at the bottom of the labour market hierarchy, for which 
they are formally overqualified (Brändle 2018; Foti 2015). In this respect, posted EU workers (Molitor 2015; Wagner and Berntsen 2016) and those working in the informal domestic and care sectors (Anderson 2000) are the most marginalised, without access to adequate social security coverage. Nevertheless, the situation has improved over recent years due to the economy's comparatively strong performance and a labour market that is increasingly characterised by a shortage of workers (SVR 2019).

Moreover, EU migrants, once they interact with local welfare and employment agencies - which may hamper their social integration efforts - often face informal barriers when seeking to access employment benefits and services. A qualitative study of German job centres documented how some eligible groups of EU migrant applicants were denied substantive receipt of the benefits to which they were legally entitled, particularly when they found themselves in situations of marginal employment (with salaries below 450 euros/month and fewer than five to ten hours of weekly work). The data pointed to instances of institutional discrimination, related to organisational blind spots with respect to EU citizens' legal entitlements and to occurrences of individual discrimination, whereby administrators relied on groupbased stereotypes and welfare chauvinist preferences when exercising discretion during claims-processing, seeking to deter applicants (Ratzmann 2019).

However, while EU and non-EU labour immigrants receive comparatively little support for integrating into their host society, state-sponsored integration policies for refugees have recently expanded in scope. As of last year, asylum-seekers can access the labour market after three months of residence in Germany. They may also participate in integration courses and vocational training while their asylum claim is under review. According to an assessment by the Expert Council for Migration and Integration, the integration courses provided are lacking in quality (SVR 2019). Moreover, channels for family reunification have been liberalised by allowing family members to immediately become active on the labour market. Asylum-seekers' labour market participation nevertheless bears practical challenges, as employers often become discouraged by their uncertain residence status. Additionally, non-recognised qualifications are commonly treated as no qualifications. However, informal skills assessments are currently being piloted. Thus, refugees' employment rates have been on the rise since 2016, with 32 per cent being economically active in 2018. Experts consider this to be a success compared to former refugees' experiences of labour market integration, which took substantially longer. Yet employment opportunities have remained confined to low-qualified, temporary jobs in the construction, service, hospitality and logistics sectors, taken up by men rather than women (SVR 2019).

Overall, insufficient language skills, a lack of local social networks and unrecognised qualifications remain the main stumbling blocks for all immigrant groups in Germany. Whilst state-sponsored integration policies were nonexistent for many years, they have recently gained in importance on the policy agenda. Whether these policies are effective in accelerating the sustainable economic and social integration of immigrants yet remains to be seen, as they tend to narrowly focus on the newcomers acquiring the German language and on their labour 
market integration. Moreover, a political approach to regulating inward migration through integration policy is increasingly discernible. Stratified access pathways to the labour market, to social security or to housing are implicated in determining which migrant groups are allowed to stay and settle in Germany. As Bommes and Geddes (2000) have argued, national social policies can act as political filters that thwart migrants' efforts to achieve social inclusion by incorporating certain kinds of migrant while excluding others.

For instance, a study of implementation dynamics in German social administration (Ratzmann 2019) unravelled how welfare bureaucrats tend to grant access to subsistence-securing social benefits, in practice, only those EU migrants whom they perceive to 'culturally fit' and who have the potential to become involved in non-marginal, gainful employment. Moreover, German legislation tightened legal benefit entitlements in 2017, now only allowing to apply for social assistance-type benefits in Germany those EU migrants who have 'worker status'. The ways in which policy is implemented allow all EU citizens to move freely but not all are made to feel welcome and enabled to residing without restrictions in their memberstate of choice. It may be argued that local-level processes of enabling or refusing access to basic income benefits create a filter with which to keep EU migrants who are deemed 'unproductive' from settling by depriving them of any state support in their host country. In the absence of traditional instruments of migration control, local implementers may engender an informal rebordering of the internal, borderless Schengen Area through keeping certain types of EU migrant in precarious living conditions. Every day, almost invisible functional borders against EU citizens shape who can afford to stay in Germany (Ratzmann 2019).

In light of this, social integration efforts might have to be rethought in a more holistic manner to facilitate migrants' meaningful societal participation in Germany as equal conationals. Public legislators may have to address questions of policy coherence, considering that fields beyond classic immigration policy affect newcomers' settlement in Germany - fields such as labour market and social security policies, whose goals may conflict with the logics of migration control through selective immigration policy. This also includes questions of political representation and visibility in the public sector, especially schools and administration. Moreover, the role of federal and local government in migration and integration politics might be worth rethinking. To date, the federal level is solely responsible for shaping immigration policy, while regions and cities have very little or virtually no voice. As for integration policies, local government has a more active role than the federal legislator, especially when it comes to insuring the social cohesion and inclusion of migrant residents locally. While both policy areas tend to be legislated and implemented independent of one another, they nevertheless commonly interact and thus would need to be codeveloped jointly.

\section{Conclusion}

This chapter has traced the developments of German immigration and integration policies since the antecedent of the postwar period. Policies regulating immigrants' entry have existed for decades. As immigration tended to be seen 
as predominantly of a temporary nature, policy-makers did not perceive a structured policy to foster the sustainable integration of migrants and their descendants into society to be a necessity. However, in recent years, the country's integration paradigm has undergone a fundamental shift. Not least, the inflow of a substantial number of refugees in 2015 and 2016 illustrated the need for more effective integration policies. The considerable number of new laws and adjustments to existing laws concerning migration and integration issues in the last decade hints at the German government's willingness to pro-actively address the challenges of migration-related diversity.

What remains open to debate is whether ideas about nationhood have merely changed on paper. To date, cultural markers of belonging continue to be embedded into policy design, filtering immigrants based on their 'cultural fit'. Evidence also suggests that public-service providers continuously abide by assimilationist understandings of integration and tend to discriminate against residents with a migration background (Ratzmann 2018; see also Hemker and Rink 2017). While policy cannot prescribe integration efforts, it has the potential to steer perceptions of 'cultural integration', which oscillate between civic duties of abiding by the German constitution and the prescriptive norms of everyday life. A move away from a 'deficit' or 'cultural assimilationist' perspective, addressing instead the shortcomings of what immigrants 'lack' compared to German-born nationals, may be required. Questions further persist as to whether perceptions of diversity as a resource and value in and of itself have trickled down to the local level or whether understandings of integration as an interactive process aimed at ensuring the meaningful participation of all residents remain confined to the policy rather than the implementation level.

\section{Note}

1 See http://ec.europa.eu/commfrontoffice/publicopinion/index.cfm/Chart/index (accessed 28 September 2019).

\section{References}

Amjahid, Mohamed (2017) Unter Weissen. Was es heisst, privilegiert zu sein. Auflage 1. München: Hanser Berlin im Carl Hanser Verlag.

Anderson, B. (1983) Imagined Communities. London: Verso.

Anderson, B. (2000) Doing the Dirty Work? The Global Politics of Domestic Labour. New York/London: Zed Books.

Barrett, A. (2012) Welfare and Immigration. MPC Research Report 2012/07. Fiesole: Robert Schuman Centre for Advanced Studies, Migration Policy Centre.

Barrett, A. and Maître, B. (2011) Immigrant Welfare Receipt across Europe. Bonn: Institute of Labor, IZA Discussion Paper No. 5515.

Basilio, L., Bauer, T.K. and Kramer, A. (2017) 'Transferability of human capital and immigrant assimilation: An analysis for Germany', LABOUR: Review of Labour Economics and Industrial Relations, 31(3): 245-264.

Bauer, T.K. (2002) 'Migration, Sozialstaat und Zuwanderungspolitik', Vierteljahreshefte zur Wirtschaftsforschung, 71(2): 249-271. 
Bauer, T.K., Dietz, B., Zimmermann, K.F. and Zwintz, E. (2005) 'German migration: Development, assimilation, and labour market effects', in Zimmermann, K.F. (ed.) European Migration: What Do We Know? Oxford: Oxford University Press, pp. 197-261.

Bauer, T.K., Lofstrom, M. and Zimmermann, K.F. (2000) 'Immigration policy, assimilation of immigrants and natives' sentiments towards immigrants. Evidence from 12 OECD countries', Swedish Economic Policy Review, 7(2): 11-53.

Bertelsmann Stiftung (2015) Willkommenskultur in Deutschland. Entwicklungen und Herausforderungen. Gütersloh: Bertelsmann Stiftung.

Bertelsmann Stiftung (2017) Willkommenskultur im 'Stresstest'. Einstellungen in der Bevölkerung 2017. Gütersloh: Bertelsmann Stiftung.

Beste, J., Bethmann, A. and Gundert, S. (2014) Sozialstruktur und Lebensumstände: Materielle und soziale Lage der ALG-II-Empfänger. Nürnberg: Institut für Arbeitsmarkt- und Berufsforschung. Available at http://doku.iab.de/kurzber/2014/kb2414.pdf (accessed 27 September 2019).

Bommes, M. and Geddes, A. (eds) (2000) Immigration and Welfare. Challenging the Borders of the Welfare State. London: Routledge.

Brändle, V.K. (2018) 'Reality bites: EU mobiles' experiences of citizenship on the local level', Journal of Ethnic and Migration Studies. doi: 10.1080/1369183X.2018.1524750.

Brubaker, R. (1992) Citizenship and Nationhood in France and Germany. Cambridge, MA: Harvard University Press.

Bruckmeier, K. and Wiemers, J. (2016) Differences in Welfare Take-Up between Immigrants and Natives. A Micro-Simulating Study. Nürnberg: Institut für Arbeitsmarkt- und Berufsforschung.

Bruzelius, C., Chase, E. and Seeleib-Kaiser, M. (2015) EU Migrant Citizens'Social Rights in Comparative Perspective. Oxford: University of Oxford, Oxford Institute of Social Policy.

Bundesamt für Migration und Flüchtlinge (2019) Migrationsbericht 2016/2017. Nürnberg: Bundesamt für Migration und Flüchtlinge.

Canceedda, A., Curtarelli, M., Hoorens, S., Viertelhauzen, T. and Hofman, J. (2015) SocioEconomic Inclusion of Migrant EU Workers in 4 Cities. Brussels: European Commission.

Davy, U. (2005) 'Integration of immigrants in Germany: A slowly evolving concept', European Journal of Migration and Law, 7(1): 123-144.

Ditlmann, R.K., Purdie-Vaughns, V. and Eibach, R.P. (2011) 'Heritage- and ideologybased national identities and their implications for immigrant citizen relations in the United States and in Germany', International Journal of Intercultural Relations, 35(4): 395-405.

Doomernik, J. and Bruquetas-Callejo, M. (2016) 'National immigration and integration policies in Europe since 1973', in Garcés-Mascareñas, B. and Penninx, R. (eds) Integration Processes and Policies in Europe: Contexts, Levels and Actors. Amsterdam: IMISCOE and Springer Open, pp. 57-76.

Dustmann, C. (1993) 'Earnings adjustment of temporary migrants', Journal of Population Economics, 6(2): 153-168.

Ellermann, A. (2015) 'Do policy legacies matter? Past and present guest worker recruitment in Germany', Journal of Ethnic and Migration Studies, 41(8): 1235-1253.

Ersanilli, E. (2010) Comparing Integration: Host Culture Adoption and Ethnic Retention among Turkish Immigrants and their Descendents in France, Germany and the Netherlands. Amsterdam: VU University of Amsterdam, Department of Sociology, unpublished $\mathrm{PhD}$ thesis. 
Faist, T. (2013) Transnational Social Protection. An Emerging Field of Study. Bielefeld: University of Bielefeld, Centre on Migration, Citizenship and Development, Working Paper No. 113.

Foti, K. (2015) Social Dimension of EU Mobility: Impact on Public Services. Luxembourg: Publications Office of the European Union.

Frings, D. (2009) Wirkungen des SGB II auf Personen mit Migrationshintergrund. Abschlussbericht. Duisburg: Universität Duisburg, Institut Arbeit und Qualifikation.

Garcés-Mascareñas, B. and Penninx, R. (eds) (2016) Integration Processes and Policies in Europe: Contexts, Levels and Actors. Amsterdam: IMISCOE and Springer Open.

Gosewinkel, D. (2016) Schutz oder Freiheit? Staatsbürgerschaft in Europa im 20. und 21. Jahrhundert. Berlin: Suhrkamp.

Hemker, J. and Rink, A. (2017) 'Multiple dimensions of bureaucratic discrimination: Evidence from German welfare offices', American Journal of Political Science, 61(4): 786-803.

Hogwood, P. (2000) 'Citizenship controversies in Germany: The twin legacy of Völkisch nationalism and the Alleinvertretungsanspruch', German Politics, 9(3): 125-144.

Jaehrling, K. and Knuth, M. (2010) 'Die Widerständigkeit von Geschlecht und Kultur im aktivierenden Sozialstaat', in Knuth, M. (ed.) Arbeitsmarktintegration und Integrationspolitik: zur notwendigen Verknüpfung zweier Politikfelder. Baden-Baden: Nomos, pp. 197-212.

Kaiser, L. and Paul, R. (2011) 'Differential inclusion in Germany's conservative welfare state: Policy legacies and structural constraints', in Carmel, E., Cerami, A. and Papadopoulos, T. (eds) Migration and Welfare in the New Europe: Social Protection and the Challenges of Integration. Portland, OR: Policy Press, pp. 121-142.

Kohn, K.H.P. (2015) Interview. Ein erster Schritt zu einem umfassenden Curriculum für migrationsspezifische Beratung. Aus: Schulungshandbuch - Grundlagen migrationsspezifischer Beratung. Edited by Fachstelle IQ Diversity Management.

Koopmans, R., Veit, S. and Yemane, R. (2018) Ethnische Hierarchien in der Bewerberauswahl. Ein Feldexperiment zu den Ursachen von Arbeitsmarktdiskriminierng. Berlin: Wissenschaftszentrum Berlin, Discussion Paper No. SP VI 2018-104.

MacGregor, N. (2014) Germany. Memories of a Nation. London: Allen Lane.

Molitor, C. (2015) Geschaeftsmodell Ausbeutung. Wenn europaeische Arbeitnehmer_innen in Deutschland um ihre Rechte betrogen werden. Bonn: Friedrich-Ebert Stiftung.

Mourão Permoser, J. (2017) 'Redefining membership. Restrictive rights and categorisation in European union migration policy', Journal of Ethnic and Migration Studies, 43(15): 2536-2555.

Paul, R. (2015) The Political Economy of Border Drawing: Arranging Legality in European Labor Migration Policies. New York: Berghahn.

Ratzmann, N. (2018) Mind the Gap. Vielfaltspolitik in der Arbeitsverwaltung. Berlin: Deutsch Plus.

Ratzmann, N. (2019) Caught between the Local and the (Trans)National EU Citizens at the Front-Line of German Welfare Policy. London: London School of Economics, unpublished $\mathrm{PhD}$ thesis.

Schierup, C.-U., Hansen, P. and Castles, S. (2006) Migration, Citizenship and the European Welfare State. Oxford: Oxford University Press.

Schönwälder, K. (2004) 'Why Germany's guestworkers were largely Europeans: The selective principles of post-war labour recruitment policy', Ethnic and Racial Studies, 27(2): 248-265. 
Sola, A. (2018) The 2015 Refugee Crisis in Germany: Concerns about Immigration and Populism. SOEP Papers on Multidisciplinary Panel Data Research. Berlin: Deutsches Institut für Wirtschaftsforschung.

Soskice, D.W. and Hall, P.A. (eds) (2001) Varieties of Capitalism: The Institutional Foundations of Comparative Advantage. Oxford/New York: Oxford University Press.

Statistisches Bundesamt (2019) Bevölkerung in Privathaushalten nach Migrationshintergrund Insgesamt. Available at www.destatis.de/DE/Themen/Gesellschaft-Umwelt/ Bevoelkerung/Migration-Integration/Tabellen/liste-migrationshintergrund-geschlecht. html (accessed 27 September 2019).

SVR (2014) Deutschlands Wandel zum modernen Einwanderungsland. Jahresgutachten 2014 mit Integrationsbarometer Berlin: Sachverstanendigenrat deutscher Stiftungen fuer Integration und Migration.

SVR (2018) Steuern, was zu steuern ist. Was können Einwanderungs- und Integrationsgesetze leisten? Berlin: Sachverstanendigenrat deutscher Stiftungen fuer Integration und Migration.

SVR (2019) Bewegte Zeiten: Rückblick auf die Integrations- und Migrationspolitik des letzten Jahres. Jahresgutachten 2019. Berlin: Sachverständigenrat deutscher Stiftungen für Integration und Migration.

Traenhardt, D. (2014) 'Germany: From ideological battles to integration consensus. Commentary', in Hollifield, J.F., Martin, P.L. and Orrenius, P.M. (eds) Controlling Immigration: A Global Perspective. Stanford, CA: Stanford University Press (3rd edition), pp. 251-255.

Triandafyllidou, A. (2001) Immigrants and National Identity in Europe. London: Routledge.

Unabhängige Kommission Zuwanderung (2001) Zuwanderung gestalten - Integration fördern. Available at http://www.fluechtlingsrat.org/download/berkommzusfas.pdf (accessed 27 September 2019).

Wagner, I. and Berntsen, L. (2016) 'Restricted rights: Obstacles in enforcing the labour rights of mobile EU workers in the German and Dutch construction sector', Transfer: European Review of Labour and Research, 22(2): 193-206.

Wunder, C. and Riphahn, R.T. (2013) 'The dynamics of welfare entry and exit amongst natives and immigrants', Oxford Economic Papers, 66(2): 580-604.

Zick, A. and Preuß, M. (2019) Einstellungen zur Integration in der deutschen Bevölkerung. Dritte Erhebung im Projekt 'Zugleich - Zugehörigkeit und Gleichwertigkeit'. Bielefeld: Stiftung Mercator. 